\title{
Effect of Fermentation Temperature and Culture Medium on Glycerol and Ethanol during Wine Fermentation
}

\author{
Gang Du, ${ }^{1,2,3}$ Jicheng Zhan, ${ }^{1}$ Jingyuan Li, ${ }^{1}$ Yiling You, ${ }^{1}$ Yu Zhao, ${ }^{1}$ \\ and Weidong Huang ${ }^{1,3 *}$
}

\begin{abstract}
Yeast strain BH8, which exhibited significant differences from nine other yeast strains studied for glycerol production, was selected to investigate the effect of fermentation temperature $\left(13\right.$ and $\left.25^{\circ} \mathrm{C}\right)$ and culture medium (synthetic medium and grape must) on fermentation kinetics, yeast growth, and glycerol and ethanol synthesis at three different stages of wine fermentation. Yeast viability was better at $13^{\circ} \mathrm{C}$ than at $25^{\circ} \mathrm{C}$ in both growth media, and the more complex grape must enabled yeast cells to reach a higher population density. The accumulation of glycerol, glycerol-3-phosphate dehydrogenase (GPD) activity, and the level of expression of the GPD1 gene were highest in the initial stages of fermentation, which potentially counteracted the hyperosmotic stress caused by the high concentration of sugar in the media. More glycerol was produced during fermentation at $25^{\circ} \mathrm{C}$ than at $13^{\circ} \mathrm{C}$ and in grape must compared to the synthetic medium at both temperatures. Ethanol production was mainly affected by fermentation temperature. More ethanol was produced at $13^{\circ} \mathrm{C}$ than at $25^{\circ} \mathrm{C}$, with lower expression of the $A D H 1$ gene and level of ADH activity. The expression of the HSP104 and ALD6 genes was induced by ethanol stress in the final stages of fermentation. The amount of glycerol produced was not correlated to the production of acetic or succinic acid.
\end{abstract}

Key words: Saccharomyces cerevisiae, glycerol, culture medium, fermentation temperature, GPD1, HSP104

Yeast cells are exposed simultaneously and sequentially to several stress conditions during alcoholic fermentation (Bauer and Pretorius 2000). When dry active Saccharomyces cerevisiae cells are inoculated into grape must they are exposed to a hyperosmotic stress caused by the high concentration of sugar in the medium ( $200 \mathrm{~g} / \mathrm{L}$ of an equimolar mixture of glucose and fructose) as well as low $\mathrm{pH}(<4)$. As fermentation proceeds, the yeast cells are affected by the progressive limitation and depletion of nutrient and by the accumulation of ethanol. Other stress factors during alcoholic fermentation can include high or low temperatures, high concentrations of $\mathrm{SO}_{2}$, and the presence of competing organisms (Bauer and Pretorius 2000). Successful production of wine depends on the ability of yeast cells to detect and respond to stress conditions without significant loss of viability (Bauer and Pretorius 2000).

As an osmolyte, glycerol plays a major role in balancing high external osmotic pressure (Blomberg and Adler 1992). The production of glycerol balances the NADH/NAD intra-

\footnotetext{
${ }^{1}$ College of Food Science and Nutritional Engineering, China Agricultural University, Beijing 100083, China; ${ }^{2}$ Tianjin Key Laboratory of Food Biotechnology, College of Biotechnology and Food Science, Tianjin University of Commerce, Tianjin 300134, China; and ${ }^{3}$ Beijing Key Laboratory of Viticulture and Enology, Beijing 100083, China.

*Corresponding author (email: huanggwd@263.net; tel: [+86]-10-62737024; fax: [+86]-10-62737553)

Acknowledgments: This work was supported by National Natural Science Foundation of China (no. 30871747) and a major program of Beijing Municipal Science and Technology Commission (no. D07060500160701).

The first two authors (G. Du and J. Zhan) contributed equally to this work.

Manuscript submitted Jul 2011, revised Sept 2011, Oct 2011, accepted Oct 2011. Publication costs of this article defrayed in part by page fees.

Copyright $(2012$ by the American Society for Enology and Viticulture. All rights reserved.

doi: 10.5344/ajev.2011.11067
}

cellular ratio (Albers et al. 1998), and glycerol, like trehalose, can act as a cryoprotectant (Izawa et al. 2004). Glycerol is nonvolatile and therefore does not contribute to the aroma of wine, but it makes a significant contribution to the sweetness of wine, with a threshold taste level of $5.2 \mathrm{~g} / \mathrm{L}$ in dry white wine, and can contribute to the body and fullness of wines (Noble and Bursick 1984). The synthesis of glycerol by the yeast $S$. cerevisiae is via the reduction of dihydroxyacetone phosphate (DHAP) by $\mathrm{NAD}^{+}$-dependent glycerol-3-phosphate dehydrogenase (GPD) followed by the dephosphorylation of glycerol 3-phosphate (glycerol 3-P) by glycerol 3-P phosphatase (GPP) (Albertyn et al. 1994a, Pahlman et al. 2001). Glycerol biosynthesis is regulated by the key enzyme GPD (Gancedo et al. 1968, Bradford 1976). The GPD1 and GPD2 genes, which encode the two isozymes of GPD (Larsson et al. 1993), are subject to different controls; for example, the expression of GPD1 is increased in response to osmotic stress, whereas the expression of GPD2 is induced under anaerobic conditions (Albertyn et al. 1994a, Pahlman et al. 2001). Hyperosmotic stress also triggers the hyperosmotic glycerol (HOG) signaling pathway, which targets GPD1 (Albertyn et al. 1994b) and the heat-inducible HSPI04 (Schuller et al. 1994). The amount of glycerol formed is influenced by several factors, including grape variety, degree of ripeness, fermentation temperature, yeast strain, agitation, and nitrogen source (Radler and Schutz 1982, Gardner et al. 1993, Omori et al. 1995, Albers et al. 1996).

In addition to glycerol, small amounts of acetic acid and succinic acid are formed in the fermentation medium and play a role in maintaining the redox balance (Van Dijken and Scheffers 1986). ALD6 is the major isoform involved in acetate formation (Remize et al. 2000a). In particular, the concentration of these compounds was enhanced in strains overproducing glycerol (Remize et al. 1999). 
In many types of fermentation, temperature is one of the most important factors in metabolite biosynthesis. The optimal temperature for $S$. cerevisiae growth is $25^{\circ} \mathrm{C}$, whereas $13^{\circ} \mathrm{C}$ is a restrictive temperature that increases the risk of stuck or sluggish fermentations (Bisson 1999). But low temperature fermentation $\left(10\right.$ to $\left.15^{\circ} \mathrm{C}\right)$ can improve taste and aroma characteristics (Feuillat et al. 1997).

Synthetic media simulating grape must are widely used in laboratory studies of wine fermentation and yeast metabolism (Riou et al. 1997). However, the complexity of the fermentative medium also affects yeast metabolism and thus the fermentation performance and the final quality of the wine. For example, glycerol yield is significantly affected by the nitrogen source in the medium (Omori et al. 1995, Albers et al. 1996). In ammonium-grown cultures, the glycerol yield is more than double that of cultures grown with an amino acid mixture as a nitrogen source. As ammonium-grown cultures require de novo amino acid synthesis, the excess NADH formed is reoxidized via glycerol synthesis. However, a nitrogen source composed primarily of ammoniacal nitrogen slightly enhanced glycerol production (Remize 2000b). These changes can be more pronounced under specific conditions, such as fermentation at lower temperatures.

There are many studies on the effects of environmental variables on glycerol and ethanol in synthetic media (Remize et al. 2000a, Izawa et al. 2004, Pérez-Torrado et al. 2002). However, few studies on metabolism of glycerol and ethanol were analyzed in the different culture media. The objective of this study was to characterize the effect of fermentation temperature $\left(13\right.$ and $\left.25^{\circ} \mathrm{C}\right)$ and culture medium (synthetic medium and grape must) on the metabolism of glycerol and ethanol during wine fermentation. These parameters could be used as the criteria for selecting wine yeast strains with high glycerol yield and resistance to low temperature.

\section{Materials and Methods}

Yeast strains. Nine commercial yeast strains independently isolated and the yeast strain BH8 (Li et al. 2010) were used (Table 1). These commercial yeast strains are widely used in wine production in China with good results. Yeast strain BH8 was isolated from spontaneously fermenting must of Beihong red winegrape (Muscat Hamburg $\times$ Vitis amurensis), a variety cultivated by the Institute of Botany, Chinese Academy of Sciences, Beijing. It has been identified as Saccharomyces cerevisiae by color and colony topography on WL nutrient agar (Pallmann et al. 2001) as well as by DNA sequence analysis conducted by the Institute of Microbiology, Chinese Academy of Sciences.

Fermentation experiments and sampling. Two media were used in this experiment. One was model synthetic medium (MSM) described by (Marullo et al. 2004). This medium (pH 3.3) contained the following components (expressed in $\mathrm{g} / \mathrm{L})$ : glucose $(100 \mathrm{~g})$, fructose $(100 \mathrm{~g})$, tartaric acid $(3 \mathrm{~g})$, citric acid (0.3 g), L-malic acid ( $0.3 \mathrm{~g}), \mathrm{MgSO}_{4}(0.2 \mathrm{~g})$, and $\mathrm{KH}_{2} \mathrm{PO}_{4}(2 \mathrm{~g})$. Assimilable nitrogen sources were adjusted to $190 \mathrm{mg}$ total $\mathrm{N} / \mathrm{L}$ as $\left(\mathrm{NH}_{4}\right)_{2} \mathrm{SO}_{4}(0.3 \mathrm{~g})$ and asparagine $(0.6 \mathrm{~g})$. Mineral salts (mg/L) were $\mathrm{MnSO}_{4} \cdot \mathrm{H}_{2} \mathrm{O}(4), \mathrm{ZnSO}_{4} \cdot 7 \mathrm{H}_{2} \mathrm{O}(4)$,
$\mathrm{CuSO}_{4} \cdot 5 \mathrm{H}_{2} \mathrm{O}(1), \mathrm{KI}(1), \mathrm{CoCl}_{2} \cdot 6 \mathrm{H}_{2} \mathrm{O}(0.4),\left(\mathrm{NH}_{4}\right)_{6} \mathrm{Mo}_{7} \mathrm{O}_{24} \cdot$ $4 \mathrm{H}_{2} \mathrm{O}(1)$, and $\mathrm{H}_{3} \mathrm{BO}_{3}(1)$. Vitamins ( $\left.\mathrm{mg} / \mathrm{L}\right)$ were mesoinositol (300), biotin (0.04), thiamin (1), pyridoxine (1), nicotinic acid (1), pantothenic acid (1), and $p$-amino benzoic acid (1). Fatty acids (mg/L) were palmitic (1), palmitoleic (0.2), stearic (3), oleic (0.5), linoleic (0.5), and linolenic (0.2).

Before yeast inoculation, the media was sterilized by filtration (nitrate cellulose membrane, $0.45 \mu \mathrm{m}$, Millipore) and supplemented with sulfur dioxide $(20 \mathrm{mg} / \mathrm{L})$ in accordance with enological treatments. The fatty acid mixture (Lavigne 1995) was prepared in ethanol solution and fixed by drying on cellulose $(0.5 \mathrm{~g} / \mathrm{L})$ to obtain $200 \mathrm{NTU}$ (nephelometric turbidity units).

The other medium was Chardonnay grape must (GM) (harvested from a vineyard in the suburbs of Beijing, 2009). The must was clarified by cold settling for $18 \mathrm{hr}$ at $10^{\circ} \mathrm{C}$ to separate the clear juice from the sediment in the presence of 20 $\mathrm{mg} / \mathrm{L}$ sulfur dioxide. The final reducing sugar concentration was adjusted to $200 \mathrm{~g} / \mathrm{L}$. Yeast assimilable nitrogen (YAN) was determined by the Aerny method (Aerny 1996) and then the grape must was made up to $190 \mathrm{mg} / \mathrm{L}$ with diammonium sulfate. Finally the $\mathrm{pH}$ was adjusted to 3.3 by aseptically adding tartaric acid $(85 \%, \mathrm{wt} / \mathrm{vol})$, which was selected because it is a compound typically found in grapes and wines and is very rarely metabolized by ascomycetous yeasts. The must was sterilized with $0.2 \%$ (vol/vol) dimethyl dicarbonate for 48 $\mathrm{hr}$ at $4^{\circ} \mathrm{C}$ to allow decomposition (Pérez-Torrado et al. 2002).

Fermentations were performed in $500 \mathrm{~mL}$ flasks with 400 $\mathrm{mL}$ medium and fitted with closures that enabled the carbon dioxide to escape and samples to be removed, but which excluded atmospheric oxygen. The initial yeast inoculums were $1 \times 10^{6}$ cells $/ \mathrm{mL}$ from YPD medium $(1 \%[\mathrm{w} / \mathrm{v}]$ yeast extract, $2 \%[\mathrm{w} / \mathrm{v}]$ peptone, and $2 \%[\mathrm{w} / \mathrm{v}]$ glucose) overnight cultures. The fermentations were conducted in triplicate at two different temperatures, $13^{\circ} \mathrm{C}$ and $25^{\circ} \mathrm{C}$, without shaking; $25^{\circ} \mathrm{C}$ was used as a reference temperature. The weight loss of the fermenters was monitored and the fermentation considered finished when the residual sugar concentration was $<4 \mathrm{~g} / \mathrm{L}$. The samples were rapidly harvested by centrifugation at 6000 $\times g$ for $5 \mathrm{~min}$ at $4^{\circ} \mathrm{C}$, washed with cold sterilized distilled

\begin{tabular}{|c|c|c|c|}
\hline \multicolumn{4}{|c|}{$\begin{array}{c}\text { Table } 1 \text { Designation, producer, and wine use of the } \\
\text { nine commercial and one laboratory Saccharomyces cerevisiae } \\
\text { strains used in the study. }\end{array}$} \\
\hline & Designation & Producer & Wine \\
\hline $\mathrm{Y1}$ & DV10 & Lallemand, France & Champagne, white \\
\hline Y2 & $\mathrm{R} 2$ & Lallemand, France & White \\
\hline Y3 & FREDDO & $\begin{array}{l}\text { Erbslöh Geisenheim } \\
\text { AG, Germany }\end{array}$ & White \\
\hline Y4 & AWRI R2 & Marivin, Australia & White \\
\hline Y5 & СҮ3079 & Lallemand, France & White \\
\hline Y6 & LVCB & DSM, Netherlands & White \\
\hline Y7 & $\mathrm{K} 1$ & Lallemand, France & White, red, ice \\
\hline Y8 & 7303 & DSM, Netherlands & Red \\
\hline Y9 & $\mathrm{XR}$ & Lamothe-Abiet, France & Red \\
\hline Y10 & $\mathrm{BH} 8$ & Laboratory, China ${ }^{a}$ & - \\
\hline
\end{tabular}

alsolated from spontaneously fermenting must of Beihong red winegrape (Muscat Hamburg $\times$ V. amurensis), Institute of Botany, Chinese Academy of Sciences, Beijing. 
water twice, and frozen in liquid nitrogen before storage at $-80^{\circ} \mathrm{C}$ until use at IF (initial fermentation, $\sim 1.070 \mathrm{~g} / \mathrm{L}$ ), MF (middle fermentation, $\sim 1.040 \mathrm{~g} / \mathrm{L}$ ), and FF (final fermentation, $\sim 0.990 \mathrm{~g} / \mathrm{L}$ ), and the supernatant was frozen at $-20^{\circ} \mathrm{C}$ prior to chemical analysis.

Density and viability measurement. Density of the ferments was measured daily by weighing $5 \mathrm{~mL}$ must. Cell viability was determined by vital staining (methylene blue stain) and microscopy as described elsewhere (Marañón 1999). Briefly, the yeast suspension was mixed (v/v) with a methylene blue solution $(0.1 \mathrm{~g} / \mathrm{L}$ methylene blue, $20 \mathrm{~g} / \mathrm{L}$ trisodium citrate, in $1 \mathrm{~L}$ binary solution) at the same temperature as the cell suspensions. At least 300 cells were counted for each aliquot.

Analytical methods. Glucose, fructose, trehalose, glycerol, succinic acid, acetic acid, and ethanol were determined (Moreira et al. 2005) by high-performance liquid chromatography using a Waters 2695 HPLC with a 2414 refractive index detector (Waters, Milford, MA). The supernatant was filtered through $0.22 \mu \mathrm{m}$ pore-size nylon filters before loading on an Aminex HPX-87H column $(300 \times 7.8 \mathrm{~mm}$; Bio-Rad, Hercules, CA) using $5 \mathrm{mM} \mathrm{H}_{2} \mathrm{SO}_{4}$ as mobile phase at $0.6 \mathrm{~mL} /$ min. The column was controlled at $65^{\circ} \mathrm{C}$.

Enzymatic assays. Approximately $10 \mathrm{mg}$ (dry mass) yeast cells were resuspended in cold $20 \mathrm{mM}$ Hepes ( $\mathrm{pH}$ 7.1) for 30 min. Cells were disrupted with an ultrasonic crusher (Ningbo Scientz Biotechnology, Ningbo, China). Cells were then centrifuged $\left(18,000 \times g\right.$ for $30 \mathrm{~min}$ at $\left.4^{\circ} \mathrm{C}\right)$ and the supernatant used as a crude enzyme solution.

The activity of glycerol-3-phosphate dehydrogenase (EC 1.1.1.8) was determined as described elsewhere (Gancedo et al. 1968) with some modifications. The reaction solution consisted of $20 \mathrm{mM}$ Hepes, $\mathrm{pH}$ 7.1, $20 \mathrm{mM} \mathrm{KCl,} 1 \mathrm{mM}$ EDTA, 1 mM DTT, $5 \mathrm{mM}$ dihydroxyacetonephosphate (DHAP), and $0.1 \mathrm{mM}$ NADH. The reaction was initiated by adding DHAP. NADH utilization was monitored spectrophotometrically at $340 \mathrm{~nm}$ and $30^{\circ} \mathrm{C}$. The molar extinction coefficient $\varepsilon_{340}$ was $6.2 \times 10^{3} / \mathrm{Mcm}$ (Blomberg and Adler 1989). One unit of enzyme activity (u) was defined as $1 \mu$ mol NADH consumed per minute. Ethanol dehydrogenase (EC 1.1.1.1) activity was determined in $50 \mathrm{mM} \mathrm{KH}_{2} \mathrm{PO} 4, \mathrm{pH} 8.0$ in the presence of 1.0 $\mathrm{mM} \mathrm{NAD}^{+}$and the reaction was started by the addition of 100 $\mathrm{mM}$ ethanol at $30^{\circ} \mathrm{C}$.

Protein concentration was determined with the Bradford assay (Bradford 1976) using bovine serum albumin (BSA) as standard. The reagents DHAP, NADH, NAD ${ }^{+}$, Hepes, DTT, and BSA were purchased from Sigma (Castle Hill, NSW, Australia).

RNA extraction and cDNA synthesis. RNA extraction was carried out using a commercial kit (TaKaRa, Otsu, Shiga, Japan) following the manufacturer's instructions. The extracted RNA was treated with RNase-Free DNase Set (Qiagen, Valencia, CA) to remove contaminating DNA and quantified by UV absorbance; the quality of the prepared RNA was assessed by running $1 \mu \mathrm{g}$ on a $1 \times$ TAE gel stained with ethidium bromide. cDNA was synthesized from the isolated RNA using oligo-dT and reverse transcriptase (Promega, Madison, WI) as recommended by the manufacturer. The cDNA was stored at $-20^{\circ} \mathrm{C}$.
Real-time PCR. Primers for the selected genes are shown (Table 2). Reactions were run in ABI qRT-PCR 7500 system (Applied Biosystems, Foster City, CA) using SYBR Premix Ex Taq (TaKaRa). Reactions were carried out in a total volume of $20 \mu \mathrm{L}$ that contained $2.0 \mu \mathrm{L}$ cDNA, $0.4 \mu \mathrm{L}$ each of forward and reverse primers $(10 \mu \mathrm{M}$ each), $10.0 \mu \mathrm{L}$ of $2 \times$ SYBR Premix Ex Taq, $0.4 \mu \mathrm{L}$ of $50 \times$ ROX Reference Dye II, and $6.8 \mu \mathrm{L} \mathrm{dH_{2 }} \mathrm{O}$. Each sample was run in triplicate. Amplifications were performed under the following conditions: $95^{\circ} \mathrm{C}$ for $15 \mathrm{~min}, 40$ cycles of $95^{\circ} \mathrm{C}$ for $15 \mathrm{sec}, 60^{\circ} \mathrm{C}$ for 34 $\mathrm{sec}$, and $95^{\circ} \mathrm{C}$ for $15 \mathrm{sec}$. At the end of the amplification cycle, a melting analysis was conducted to verify the specificity of the reaction. This analysis was carried out by heating the amplification products from 60 to $95^{\circ} \mathrm{C}$ at $0.5^{\circ} \mathrm{C} / 10 \mathrm{sec}$ and monitoring the decrease in fluorescence.

The expression of the actin gene, reported to be constitutively expressed under bioreactor wine fermentation conditions (Riou et al. 1997), was used as reference, as in previous studies (Molina et al. 2007). All data obtained with the other genes were normalized relative to this gene. In this study, the expression of the housekeeping gene $(A C T 1)$ showed a similar pattern relative to the control condition.

Statistical analysis. An analysis of variance (ANOVA) was applied to the experimental data, which was subjected to double factor analysis of variance (yeast strain/fermentation temperature). For all the statistical analyses per components, differences were considered significant at $p<0.001$. The significant differences were determined by Duncan's tests. All statistical analyses were per components using the software SAS for Windows, version 8.02 (SAS Institute Inc., Cary, NC).

\section{Results}

Effect on principal metabolites in synthetic medium. After fermentations in model synthetic medium had finished (final concentration of sugar $<4 \mathrm{~g} / \mathrm{L}$ ), results showed that both fermentation temperature and yeast strain affected metabolite concentration (Table 3). The production of glycerol, acetic acid, succinic acid, and trehalose was significantly less at $13^{\circ} \mathrm{C}$ than at $25^{\circ} \mathrm{C}$. There was less sugar residue at $13^{\circ} \mathrm{C}(1.28$ to $2.2 \mathrm{~g} / \mathrm{L})$ than at $25^{\circ} \mathrm{C}(2.15$ to $3.89 \mathrm{~g} / \mathrm{L})$, which might be due to the greater mortality by the end of fermentation at $25^{\circ} \mathrm{C}$. But the final concentration of ethanol was slightly higher at $13^{\circ} \mathrm{C}(11.7$ to $12.1 \%)$ than at $25^{\circ} \mathrm{C}(11.32$ to $11.83 \%)$.

Table 2 Primers for real-time PCR used in this study.

\begin{tabular}{lll}
\hline Primer & \multicolumn{1}{c}{ Sequence 5‘-3’ } & Reference \\
\hline ACT1-F & GATTCTGAGGTTGCTGCTTTGG & Molina et al. \\
ACT1-R & GACCCATACCGACCATGATACC & 2007 \\
ADH1-F & TCACGCTGACTTGTCTG & Molina et al. \\
ADH1-R & GCCTT GTAGACGGTGAT & 2007 \\
GPD1-F & GTTGCTAATCCAGACTTG & Zuzuarregui \\
GPD1-R & AGATAGCTCTGACGTGTG & et al. 2005 \\
HSP104-F & GCGGTCTTACCGATACCTGG & Zuzuarregui \\
HSP104-R & GACTGAGCAGGCTCGTCAAGG & et al. 2005 \\
ALD6-F & AATGTGCCGACCGTGCTT & Mizuno et al. \\
ALD6-R & ACTTAGTAGACGGCCTCTTTCTCTTG & 2006 \\
\hline
\end{tabular}


As estimated by variance analysis (Duncan test, $p<$ 0.001 ), the production of metabolites, including acetic acid, succinic acid, trehalose, and glycerol, was affected by both fermentation temperature and yeast strain, but the production of ethanol was affected only by fermentation temperature ( $p$ $<0.001)$. Concentrations of acetic acid, succinic acid, trehalose, and glycerol were significantly lower at $13^{\circ} \mathrm{C}$ than at $25^{\circ} \mathrm{C}$, whereas ethanol production increased slightly $(1.2$ to $4.06 \%$ ) at $13^{\circ} \mathrm{C}$ compared to $25^{\circ} \mathrm{C}$. In contrast to earlier observations on high and low glycerol producing strains (Radler and Schutz 1982), high glycerol formation was not correlated to high acetic acid or succinic acid production, possibly because other metabolites (in particular acetoin and 2, 3-butanediol) participate in the adjustment of the intracellular redox balance.

On the basis of these results, yeast strain BH8, which exhibited significant differences when compared with the other strains in glycerol production, was selected for studying the influence of fermentation temperature $\left(13^{\circ} \mathrm{C}\right.$ and $\left.25^{\circ} \mathrm{C}\right)$ and culture medium (synthetic medium and grape must) on fermentation kinetics, yeast growth, and the metabolism of glycerol and ethanol during wine fermentation.

Effect on fermentation kinetics and yeast growth. Temperature and culture media affected fermentation kinetics and yeast growth (Figure 1), but in each fermentation a final sugar concentration of $<4 \mathrm{~g} / \mathrm{L}$ was obtained. Fermentation was slower at $13^{\circ} \mathrm{C}$ in both growth media and the rate in grape must was two-fold higher than that in the synthetic medium at both temperatures. The fermentation in grape must finished more rapidly ( 9 and 25 days at $25^{\circ} \mathrm{C}$ and $13^{\circ} \mathrm{C}$, respectively) than that in the synthetic medium $\left(21\right.$ and 45 days at $25^{\circ} \mathrm{C}$ and $13^{\circ} \mathrm{C}$, respectively).
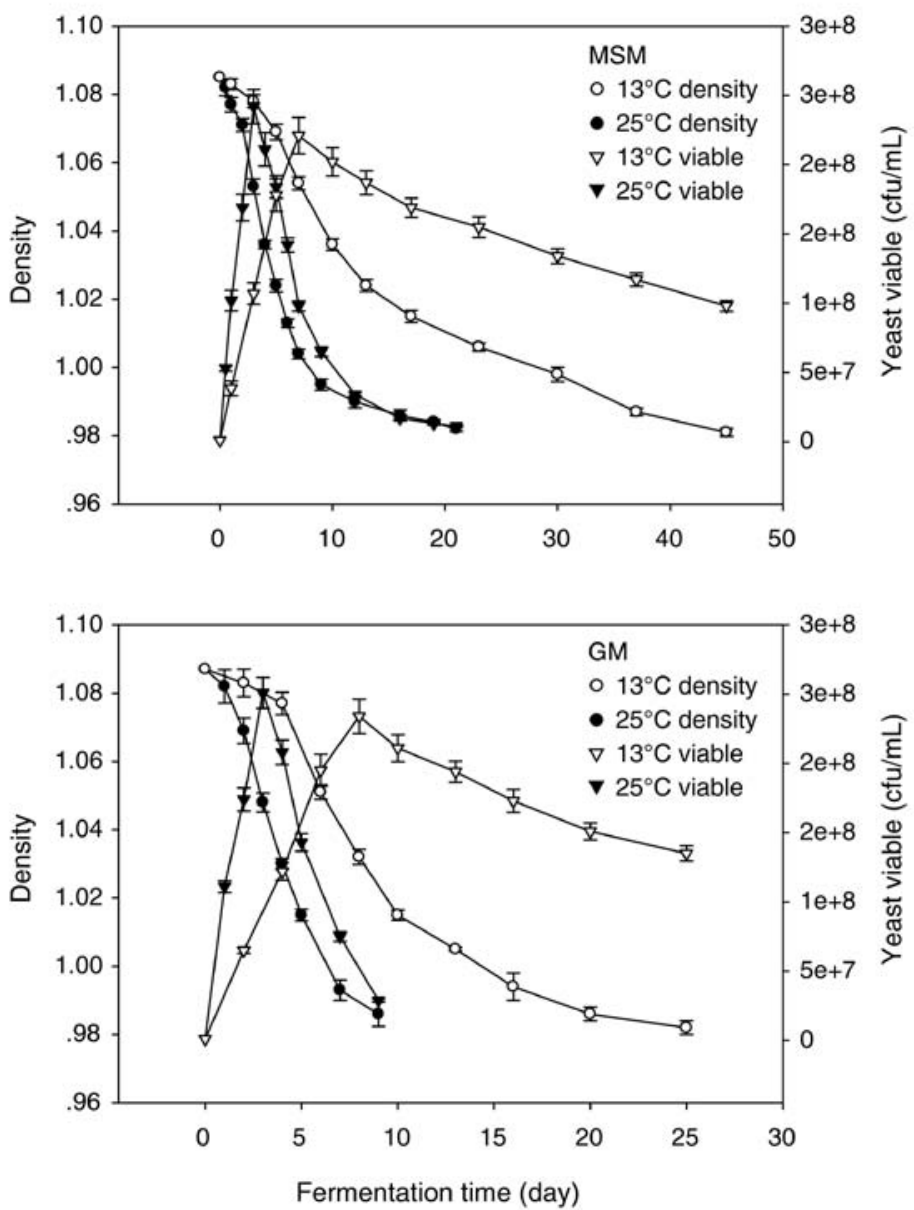

Figure 1 Effect of fermentation temperature $\left(13\right.$ and $\left.25^{\circ} \mathrm{C}\right)$ and culture media (model synthetic medium: MSM; grape must: GM) on fermentation kinetics and yeast growth.

\begin{tabular}{|c|c|c|c|c|c|c|c|}
\hline Strain & & $\begin{array}{c}\text { Final ethanol } \\
(\%, v / v)\end{array}$ & $\begin{array}{c}\text { Glycerol } \\
(\mathrm{g} / \mathrm{L})\end{array}$ & $\begin{array}{c}\text { Trehalose } \\
(\mathrm{g} / \mathrm{L})\end{array}$ & $\begin{array}{c}\text { Acetic acid } \\
(\mathrm{mg} / \mathrm{L})\end{array}$ & $\begin{array}{l}\text { Succinic acid } \\
(\mathrm{mg} / \mathrm{L})\end{array}$ & $\begin{array}{c}\text { Sugar residue } \\
(\mathrm{g} / \mathrm{L})\end{array}$ \\
\hline \multirow[t]{2}{*}{$\mathrm{Y} 1$} & $25^{\circ} \mathrm{C}$ & $11.75 \pm 0.07^{a}$ & $8.91 \pm 0.17^{a}$ & $1.36 \pm 0.13^{a}$ & $807 \pm 12^{a}$ & $1250 \pm 23^{a}$ & $3.14 \pm 0.3^{a}$ \\
\hline & $13^{\circ} \mathrm{C}$ & $11.91 \pm 0.02^{a}$ & $6.24 \pm 0.03^{a}$ & $0.94 \pm 0.01^{a}$ & $612 \pm 23^{a}$ & $560 \pm 34^{a}$ & $1.45 \pm 0.04^{a}$ \\
\hline \multirow[t]{2}{*}{ Y2 } & $25^{\circ} \mathrm{C}$ & $11.61 \pm 0.04^{a}$ & $8.34 \pm 0.15^{a}$ & $1.42 \pm 0.09^{a}$ & $936 \pm 15^{a}$ & $1888 \pm 24^{a}$ & $2.98 \pm 0.19^{a}$ \\
\hline & $13^{\circ} \mathrm{C}$ & $11.75 \pm 0.12^{\mathrm{a}}$ & $6.25 \pm 0.13^{a}$ & $0.86 \pm 0.02^{a}$ & $710 \pm 34^{a}$ & $510 \pm 42^{a}$ & $1.32 \pm 0.03^{a}$ \\
\hline \multirow[t]{2}{*}{ Y3 } & $25^{\circ} \mathrm{C}$ & $11.55 \pm 0.03^{a}$ & $8.85 \pm 0.41^{a}$ & $1.51 \pm 0.04^{\mathrm{a}}$ & $859 \pm 21^{a}$ & $1600 \pm 54^{a}$ & $2.95 \pm 0.16^{a}$ \\
\hline & $13^{\circ} \mathrm{C}$ & $11.86 \pm 0.28^{a}$ & $6.09 \pm 0.11^{a}$ & $1.02 \pm 0.09^{a}$ & $652 \pm 34^{a}$ & $480 \pm 25^{a}$ & $1.78 \pm 0.14^{a}$ \\
\hline \multirow[t]{2}{*}{ Y4 } & $25^{\circ} \mathrm{C}$ & $11.83 \pm 0.02^{a}$ & $8.4 \pm 0.46^{a}$ & $1.3 \pm 0.06^{a}$ & $829 \pm 21^{a}$ & $1485 \pm 32^{a}$ & $2.15 \pm 0.15^{\mathrm{a}}$ \\
\hline & $13^{\circ} \mathrm{C}$ & $12.1 \pm 0.05^{a}$ & $6.98 \pm 0.03^{a}$ & $1.07 \pm 0.02^{a}$ & $624 \pm 34^{a}$ & $795 \pm 43^{a}$ & $1.35 \pm 0.13^{a}$ \\
\hline \multirow[t]{2}{*}{ Y5 } & $25^{\circ} \mathrm{C}$ & $11.54 \pm 0.14^{\mathrm{a}}$ & $8.49 \pm 0.24^{a}$ & $1.3 \pm 0.05^{\mathrm{a}}$ & $872 \pm 12^{\mathrm{a}}$ & $1005 \pm 21^{a}$ & $3.03 \pm 0.17^{a}$ \\
\hline & $13^{\circ} \mathrm{C}$ & $11.7 \pm 0.2^{\mathrm{a}}$ & $6.33 \pm 0.15^{a}$ & $1.01 \pm 0.02^{\mathrm{a}}$ & $501 \pm 23^{a}$ & $412 \pm 23^{a}$ & $1.78 \pm 0.14^{a}$ \\
\hline \multirow[t]{2}{*}{ Y6 } & $25^{\circ} \mathrm{C}$ & $11.5 \pm 0.08^{a}$ & $7.98 \pm 0.09^{a}$ & $1.21 \pm 0.12^{\mathrm{a}}$ & $938 \pm 21^{a}$ & $1172 \pm 23^{a}$ & $2.72 \pm 0.14^{a}$ \\
\hline & $13^{\circ} \mathrm{C}$ & $11.77 \pm 0.06^{a}$ & $6.66 \pm 0.17^{a}$ & $0.83 \pm 0.02^{\mathrm{a}}$ & $730 \pm 12^{a}$ & $662 \pm 24^{a}$ & $1.28 \pm 0.08^{a}$ \\
\hline \multirow[t]{2}{*}{ Y7 } & $25^{\circ} \mathrm{C}$ & $11.32 \pm 0.04^{a}$ & $7.44 \pm 0.24^{a}$ & $1.38 \pm 0.05^{a}$ & $955 \pm 13^{a}$ & $1475 \pm 57^{a}$ & $2.84 \pm 0.13^{a}$ \\
\hline & $13^{\circ} \mathrm{C}$ & $11.78 \pm 0.05^{a}$ & $5.29 \pm 0.03^{a}$ & $0.76 \pm 0.02^{\mathrm{a}}$ & $720 \pm 21^{a}$ & $808 \pm 32^{a}$ & $1.32 \pm 0.03^{a}$ \\
\hline \multirow[t]{2}{*}{ Y8 } & $25^{\circ} \mathrm{C}$ & $11.44 \pm 0.05^{a}$ & $9.44 \pm 0.5^{a}$ & $1.52 \pm 0.1^{\mathrm{a}}$ & $867 \pm 18^{a}$ & $1509 \pm 46^{a}$ & $3.79 \pm 0.21^{a}$ \\
\hline & $13^{\circ} \mathrm{C}$ & $11.82 \pm 0.03^{a}$ & $6.49 \pm 0.1^{\mathrm{a}}$ & $1 \pm 0.03^{a}$ & $660 \pm 34^{a}$ & $475 \pm 14^{a}$ & $1.8 \pm 0.03^{a}$ \\
\hline \multirow[t]{2}{*}{ Y9 } & $25^{\circ} \mathrm{C}$ & $11.46 \pm 0.07^{a}$ & $9.08 \pm 0.78^{a}$ & $1.29 \pm 0.04^{a}$ & $745 \pm 12^{\mathrm{a}}$ & $1375 \pm 59^{a}$ & $3.89 \pm 0.23^{a}$ \\
\hline & $13^{\circ} \mathrm{C}$ & $11.78 \pm 0.17^{a}$ & $5.36 \pm 0.11^{a}$ & $0.81 \pm 0.02^{\mathrm{a}}$ & $538 \pm 23^{a}$ & $685 \pm 32^{a}$ & $2.2 \pm 0.09^{a}$ \\
\hline \multirow[t]{2}{*}{$\mathrm{Y} 10$} & $25^{\circ} \mathrm{C}$ & $11.59 \pm 0.03^{a}$ & $10.63 \pm 0.52^{a}$ & $1.15 \pm 0.06^{a}$ & $790 \pm 32^{a}$ & $1234 \pm 98^{a}$ & $3.65 \pm 0.11^{a}$ \\
\hline & $13^{\circ} \mathrm{C}$ & $11.7 \pm 0.11^{a}$ & $8.47 \pm 0.57^{a}$ & $0.81 \pm 0.04^{a}$ & $603 \pm 32^{a}$ & $807 \pm 32^{a}$ & $1.76 \pm 0.04^{a}$ \\
\hline
\end{tabular}

aMean value and SD for three independent fermentations. 
Yeast grew quickly at $25^{\circ} \mathrm{C}$, reaching higher maximal cell density $\left(2.42 \times 10^{8}\right.$ cells $/ \mathrm{mL}$ in the synthetic medium and 2.51 $\times 10^{8}$ cells $/ \mathrm{mL}$ in must $)$ than at $13^{\circ} \mathrm{C}\left(2.21 \times 10^{8}\right.$ cells $/ \mathrm{mL}$ in the synthetic medium and $2.34 \times 10^{8}$ cells $/ \mathrm{mL}$ in must). At $25^{\circ} \mathrm{C}$, the exponential phase was relatively brief but viability began to decrease after entering the stationary phase. In contrast, yeast grew slowly at $13^{\circ} \mathrm{C}$, but viability was more or less constant until the end of fermentation. The cell growth profile was similar in both culture media, but the cell population was higher in must than in synthetic medium. These effects might be related to different compositions of the cell membrane, mainly due to the increase in fatty acid unsaturation in yeast cells, which improves ethanol tolerance and increases cell viability (Alexandre et al. 1994).

Effect on glycerol production, enzyme activity, and gene expression levels. Measurements were made at three stages of fermentation: initial fermentation (IF, density $\sim 1.070$ $\mathrm{g} / \mathrm{L}$ ), when yeast cells were multiplying exponentially and only slight ethanol concentration was produced; midfermentation (MF, density $\sim 1.040 \mathrm{~g} / \mathrm{L}$ ), when yeast cultures were at the start of the nonproliferating phase, with $\sim 50 \%$ of the sugar consumed and ethanol concentration was $\sim 5$ to $6 \%(\mathrm{v} / \mathrm{v})$; and final fermentation (FF, density $\sim 0.990 \mathrm{~g} / \mathrm{L}$ ), when fermentation was arrested and the medium contained residual sugars $(<10 \mathrm{~g} / \mathrm{L})$ and high ethanol concentration $(>10 \%, \mathrm{v} / \mathrm{v})$.

The effects of temperature and culture medium on glycerol production, GPD activity, and GPD1 and HSP104 gene expression are shown in Figure 2. Glycerol production increased with time and was higher at $25^{\circ} \mathrm{C}$ than at $13^{\circ} \mathrm{C}$ in both culture media, but fermentation at $13^{\circ} \mathrm{C}$ produced slightly more glycerol than at $25^{\circ} \mathrm{C}$ in the IF stage. Glycerol production was higher in grape must than in the synthetic medium at both fermentation temperatures. Approximately $40 \%$ of the total glycerol yield was produced during the IF stage.

GPD activity and GPD1 expression decreased with time probably because the high concentration of sugar in the IF stage induced the yeast cells to produce more glycerol, which acts as an osmolyte and balances the high external osmotic pressure. GPD activity and GPD1 gene expression were higher at $25^{\circ} \mathrm{C}$ than at $13^{\circ} \mathrm{C}$ in both culture media. In the FF stage, GPD activity and GPD1 expression were lowest in the synthetic medium at $25^{\circ} \mathrm{C}$. GPD activity and GPD1 expression were higher in grape must than in synthetic medium at both fermentation temperatures. HSP104 expression was low and changed only slightly in the IF and MF stages but increased in the FF stage. HSP104 expression was similar in both culture media at both temperatures but was slightly higher at $13^{\circ} \mathrm{C}$ than at $25^{\circ} \mathrm{C}$.

Effect on ethanol production, enzyme activity, and gene expression levels. The effect of fermentation temperature and culture media on the production of ethanol, ADH activity, and $A D H 1$ and $A L D 6$ gene expression is shown in Figure 3. Ethanol production increased with time and was strongly affected by temperature at the IF and MF stages and was slightly higher at $13^{\circ} \mathrm{C}$ than $25^{\circ} \mathrm{C}$ at the FF stage. Ethanol production was higher in grape must than in the synthetic medium at both temperatures.
As expected, changes of ADH activity and $A D H 1$ expression were similar. They were highest in the MF stage, much higher at $25^{\circ} \mathrm{C}$ than at $13^{\circ} \mathrm{C}$ in both culture media, and higher in grape must than in the synthetic medium at both temperatures.

The production of acetate, which is an undesirable component in wine, is enhanced when using yeast strains that overproduce glycerol (Remize et al. 1999). ALD6 expression was low and changed only slightly at the IF and MF stages, but it increased at the FF stage when $A D H 1$ expression decreased. The change in ALD6 expression was similar in both media and at both temperatures, but it was slightly lower at $13^{\circ} \mathrm{C}$ than at $25^{\circ} \mathrm{C}$ in both culture media.

\section{Discussion}

Several studies have shown increased glycerol production during vinification under stress conditions (Remize et al.
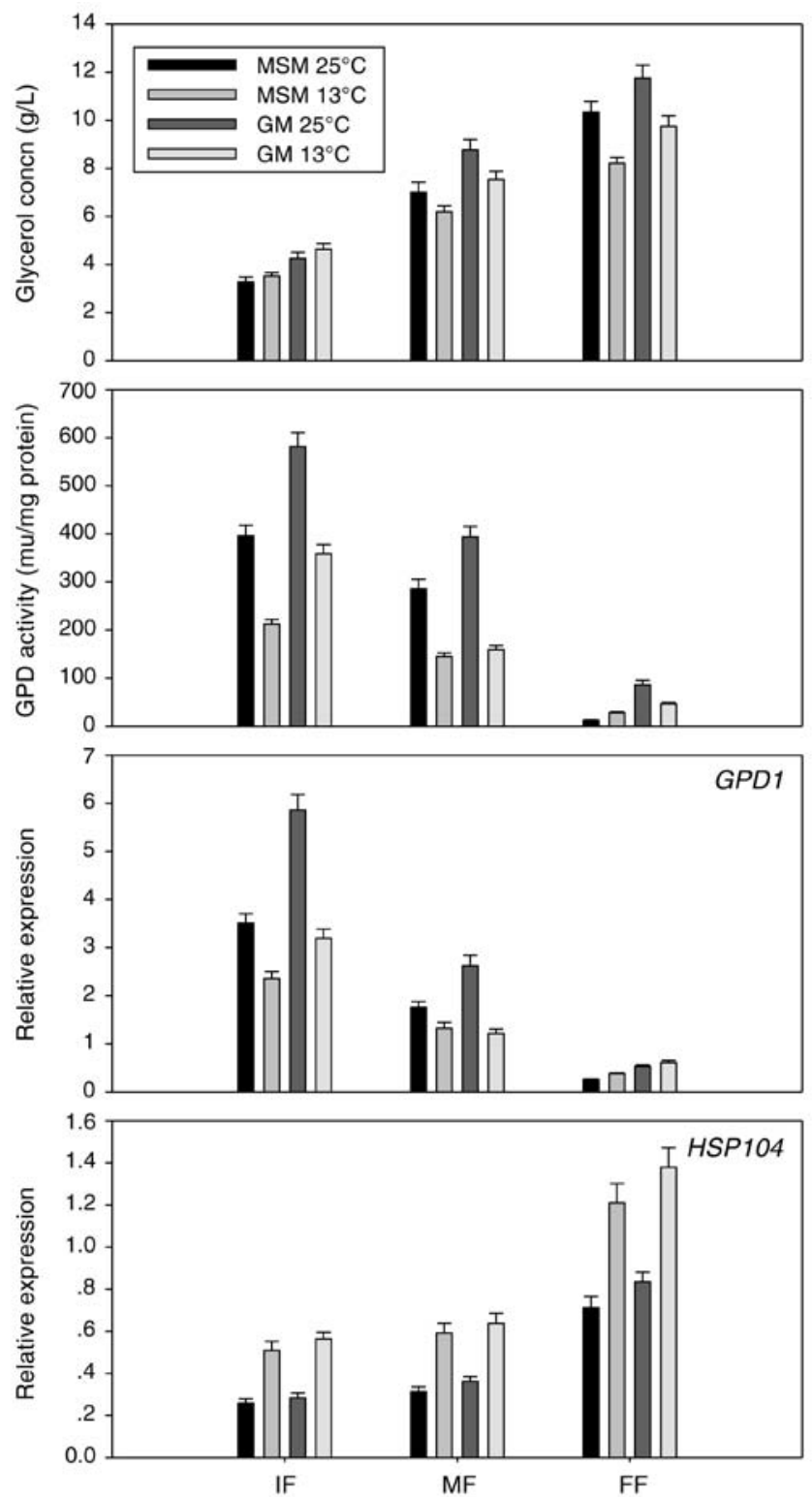

Figure 2 Effect of fermentation temperature and culture media (model synthetic medium: MSM; grape must: GM) on glycerol production, GPD activity, and gene expression levels of GPD1 and HSP104. Error bars indicate standard errors from three independent samples. 
2000a, Izawa et al. 2004, Pérez-Torrado et al. 2002). Little effort has been invested in understanding the links between ethanol and glycerol metabolism in grape must. Results here showed that several environmental factors (e.g., fermentation temperature, culture medium, yeast strain) affected glycerol production but that ethanol production was mainly affected by the fermentation temperature. Concentrations of acetic acid, succinic acid, trehalose, and glycerol were significantly lower at $13^{\circ} \mathrm{C}$ than at $25^{\circ} \mathrm{C}$, whereas ethanol production increased slightly $(1.2$ to $4.06 \%)$ at $13^{\circ} \mathrm{C}$ compared to $25^{\circ} \mathrm{C}$.

The peaks of GPD activity and GPD1 expression were highest in IF, and $\sim 40 \%$ of the total glycerol yield was produced during this stage. These results are in accord with the requirement for glycerol production to counteract the hyperosmotic stress imposed by the high levels of sugar present at the IF stage (Van Dijck et al. 2000). Glycerol production was
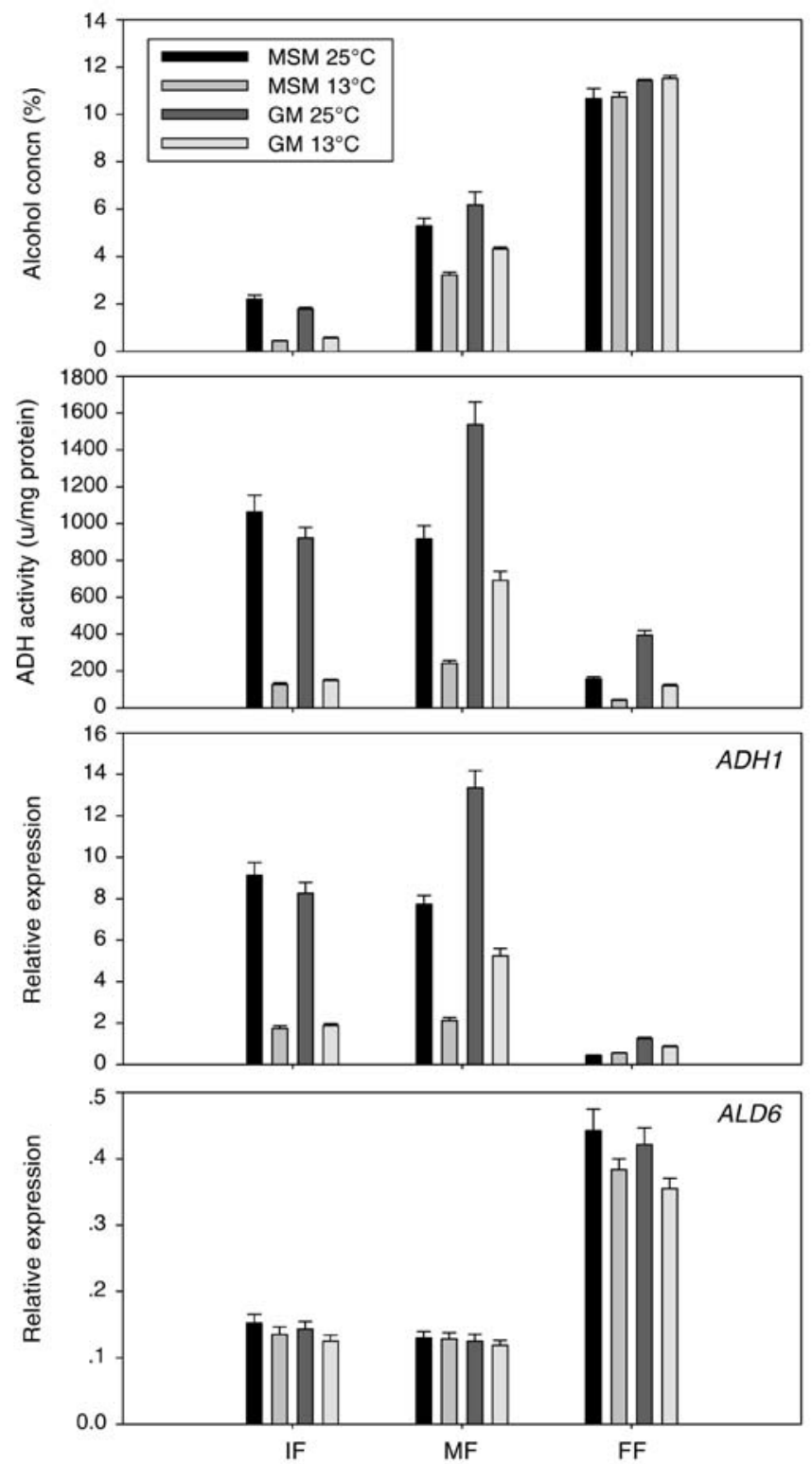

Figure 3 Effect of fermentation temperature and culture media (model synthetic medium: MSM; grape must: GM) on alcohol production, ADH activity, and gene expression levels of $A D H 1$ and $A L D 6$. Error bars indicate standard errors from three independent samples. much higher at $25^{\circ} \mathrm{C}$ than at $13^{\circ} \mathrm{C}$ in both culture media but was slightly higher at $13^{\circ} \mathrm{C}$ than at $25^{\circ} \mathrm{C}$ in the IF stage, which could be related to cold stress (Izawa et al. 2004). Glycerol accumulation could induce yeast cells to adapt their physiology to lower than optimal temperatures. Glycerol production, GPD activity, and GPDI expression were much higher in grape must than in the synthetic medium at both temperatures and at the three stages of fermentation, likely due to some substances activating the key enzyme of glycerol synthesis. The hyperosmotic glycerol (HOG) signaling pathway targets HSP104. Yet HSP104 expression was not induced by heat shock or other forms of stress (e.g., osmotic stress) in the IF stage. This outcome is best explained by the HOG pathway exerting only limited control over GPDI expression and glycerol production during wine fermentation (Remize et al. 2003) and the optimal temperature of $25^{\circ} \mathrm{C}$ for fermentation was not a stressful condition for S. cerevisiae. However, HSP104 expression was highest in the $\mathrm{FF}$ stage at $13^{\circ} \mathrm{C}$ in this study. These results suggested that $\mathrm{HSP} 104$ expression was probably induced by ethanol stress or cold stress (Marks et al. 2008).

Fermentation at $13^{\circ} \mathrm{C}$ with lower ADH activity and $A D H 1$ expression produced more ethanol than at $25^{\circ} \mathrm{C}$. Although losses due to evaporation at high temperature are expected, the main cause of this reduction is probably the increase of products of other metabolic pathways such as glycerol, acetic acid, succinic acid, and trehalose (Torija et al. 2003). Fermentation in grape must with relatively higher ADH activity and $A D H 1$ expression produced more ethanol than in the synthetic medium, which was probably due to some substances activating the $\mathrm{ADH}$ activity. $A L D 6$ expression was relatively low at all three stages of fermentation. In contrast to earlier observations on high and low glycerol-producing strains (Radler and Schutz 1982), high glycerol formation was not correlated to high acetic acid or succinic acid production, possibly because other metabolites (in particular acetoin and 2,3-butanediol) participate in the adjustment of the intracellular redox balance. ALD6 expression was higher at the FF stage, suggesting that it was induced by ethanol stress.

\section{Conclusion}

Results show that, within the constraints of winemaking, achieving a high yield of glycerol requires the selection or improvement of yeast strains for high production of glycerol and adaptation to low-temperature fermentation. To date, the functions of HSP104 and ALD6 and the mechanism of glycerol metabolism are not fully understood. Further studies should address these areas, which would aid in the selection of wine yeasts and improve wine quality.

\section{Literature Cited}

Aerny, J. 1996. Composés azotés des moûts et vins. Rev. Suisse Vitic. Arboric. Hortic. 28:161-165.

Albers, E., C. Larsson, G. Lidén, C. Niklasson, and L. Gustafsson. 1996. Influence of the nitrogen source on Saccharomyces cerevisiae anaerobic growth and product formation. Appl. Environ. Microb. 62:3187-3195.

Albers, E., G. Lidén, C. Larsson, and L. Gustafsson. 1998. Anaerobic redox balance and nitrogen metabolism in Saccharomyces cerevisiae. Recent Res. Devel. Microbiol. 2:253-279. 
Albertyn, J., S. Hohmann, J.M. Thevelein, and B.A. Prior. 1994a. GPD1, which encodes glycerol-3-phosphate dehydrogenase, is essential for growth under osmotic stress in Saccharomyces cerevisiae, and its expression is regulated by the high-osmolarity glycerol response pathway. Mol. Cell. Biol. 14:4135-4144.

Albertyn, J., S. Hohmann, and B.A. Prior. 1994b. Characterization of the osmotic-stress response in Saccharomyces cerevisiae: Osmotic stress and glucose repression regulate glycerol-3-phosphate dehydrogenase independently. Curr. Genet. 25:12-18.

Alexandre, H., I. Rousseaux, and C. Charpentier. 1994. Ethanol adaptation mechanisms in Saccharomyces cerevisiae. Biotechnol. Appl. Biochem. 20:173-183.

Bauer, F.F., and I.S. Pretorius. 2000. Yeast stress response and fermentation efficiency: How to survive the making of wine-A review. S. Afr. J. Enol. Vitic. 21:27-51.

Bisson, L.F. 1999. Stuck and sluggish fermentations. Am. J. Enol. Vitic. 50:107-119.

Blomberg, A., and L. Adler. 1989. Roles of glycerol and glycerol3 -phosphate dehydrogenase $\left(\mathrm{NAD}^{+}\right)$in acquired osmotolerance of Saccharomyces cerevisiae. J. Bacteriol. 171:1087-1092.

Blomberg, A., and L. Adler. 1992. Physiology of osmotolerance in fungi. Adv. Microb. Physiol. 33:145-212.

Bradford, M.M. 1976. A rapid and sensitive method for the quantitation of microgram quantities of protein utilizing the principle of protein-dye binding. Anal. Biochem. 72:248-254.

Feuillat, M., C. Charpentier, and C. Massoutier. 1997. Intérêt oenologique des souches de levures Saccharomyces cryotolérantes. Rev. Oenol. 85:18-21.

Gancedo, C., J.M. Gancedo, and A. Sols. 1968. Glycerol metabolism in yeasts. Pathways of utilization and production. Eur. J. Biochem. $5: 165-172$.

Gardner, N., N. Rodrigue, and C.P. Champagne. 1993. Combined effects of sulfites, temperature, and agitation time on production of glycerol in grape juice by Saccharomyces cerevisiae. Appl. Environ. Microb. 59:2022-2028.

Izawa, S., M. Sato, K. Yokoigawa, and Y. Inoue. 2004. Intracellular glycerol influences resistance to freeze stress in Saccharomyces cerevisiae: Analysis of a quadruple mutant in glycerol dehydrogenase genes and glycerol-enriched cells. Appl. Microbiol. Biotechnol. $66: 108-114$

Larsson, K., R. Ansell, P. Eriksson, and L. Adler. 1993. A gene encoding $s n$-glycerol 3-phosphate dehydrogenase $\left(\mathrm{NAD}^{+}\right)$complements an osmosensitive mutant of Saccharomyces cerevisiae. Mol. Microbiol. 10:1101-1111.

Lavigne, V. 1995. Origine du méthionol dans les vins blancs secs. In (Enologie 95: 5e Symposium International d'Enologie. A. LonvaudFunel (ed.), pp. 251-255. Lavoisier TEC \& Doc, Paris.

Li, H., H.L. Wang, J. Du, G. Du, J.C. Zhan, and W.D. Huang. 2010. Trehalose protects wine yeast against oxidation under thermal stress. World J. Microbiol. Biotech. 26:969-976.

Marañón, I.M.D., N. Chaudanson, N. Joly, and P. Gervais. 1999. Slow heat rate increases yeast thermotolerance by maintaining the plasma membrane integrity. Biotechnol. Bioeng. 65:176-181.

Marks, V.D., S.J. Ho Sui, D. Erasmus, G.K. van der Merwe, J. Brumm, W.W. Wasserman, J. Bryan, and H.J. van Vuuren. 2008. Dynamics of the yeast transcriptome during wine fermentation reveals a novel fermentation stress response. FEMS Yeast Res. 8:35-52.

Marullo, P., M. Bely, I. Masneuf, M. Aigle, and D. Dubourdieu. 2004. Inheritable nature of enological quantitative traits is demonstrated by meiotic segregation of industrial wine yeast strains. FEMS Yeast Res. 7:711-719.

Mizuno, A., H. Tabei, and M. Iwahuti. 2006. Characterization of low-acetic-acid-producing yeast isolated from 2-deoxyglucoseresistant mutants and its application to high-gravity brewing. J. Biosci. Bioeng. 101:31-37.
Molina, A.M., J.H. Swiegers, C. Varela, I.S. Pretorius, and E. Agosin. 2007. Influence of wine fermentation temperature on the synthesis of yeast-derived volatile aroma compounds. Appl. Microbiol. Biotech. 77:675-687.

Moreira, N., F. Mendes, T. Hogg, and I. Vasconcelos. 2005. Alcohols, esters and heavy sulphur compounds production by pure and mixed cultures of apiculate wine yeasts. Int. J. Food. Microbiol. 103:285-294.

Noble, A.C., and G.F. Bursick. 1984. The contribution of glycerol to perceived viscosity and sweetness in white wine. Am. J. Enol. Vitic. 35:110-112.

Omori, T., H. Takashita, N. Omori, and M. Shimoda. 1995. High glycerol producing amino acid analogue-resistant Saccharomyces cerevisiae mutant. J. Ferment. Bioeng. 80:218-222.

Pahlman, A.K., K. Granath, R. Ansell, S. Hohmann, and L. Adler. 2001. The yeast glycerol-3-phosphatases Gpplp and Gpp2p are required for glycerol biosynthesis and differentially involved in the cellular responses to osmotic, anaerobic, and oxidative stress. J. Biol. Chem. 276:3555-3563

Pallmann, C.L., J.A. Brown, T.L. Olineka, L. Cocolin, D.A. Mills, and L.F. Bisson. 2001. Use of WL medium to profile native flora fermentations. Am. J. Enol. Vitic. 52:198-203.

Pérez-Torrado, R., J.V. Gimeno-Alcañiz, and E. Matallana. 2002. Wine yeast strains engineered for glycogen overproduction display enhanced viability under glucose deprivation conditions. Appl. Environ. Microbiol. 68:3339-3344.

Radler, F., and H. Schütz. 1982. Glycerol production of various strains of Saccharomyces. Am. J. Enol. Vitic. 33:36-40.

Remize, F., J.L. Roustan, J.M. Sablayrolles, P. Barre, and S. Dequin. 1999. Glycerol overproduction by engineered Saccharomyces cerevisiae wine yeast strains leads to substantial changes in by-product formation and to a stimulation of fermentation rate in stationary phase. Appl. Environ. Microbiol. 65:143-149.

Remize, F., E. Andrieu, and S. Dequin. 2000a. Engineering of the pyruvate dehydrogenase bypass in Saccharomyces cerevisiae: Role of the cytosolic $\mathrm{Mg}^{2+}$ and mitochondrial $\mathrm{K}^{+}$acetaldehyde dehydrogenases Ald6 $p$ and Ald $4 p$ in acetate formation during alcoholic fermentation. Appl. Environ. Microbiol. 66:3151-3159.

Remize, F., J.M. Sablayrolles, and S. Dequin. 2000b. Re-assessment of the influence of yeast strain and environmental factors on glycerol production in wine. J. Appl. Microbiol. 88:371-378.

Remize, F., B. Cambon, L. Barnavon, and S. Dequin. 2003. Glycerol formation during wine fermentation is mainly linked to Gpd1p and is only partially controlled by the HOG pathway. Yeast 20:1243-1253.

Riou, C., J.M. Nicaud, P. Barre, and C. Gaillardin. 1997. Stationaryphase gene expression in Saccharomyces cerevisiae during wine fermentation. Yeast 13:903-915.

Schuller, C., J.L. Brewster, M.R. Alexander, M.C. Gustin, and H. Ruis. 1994. The HOG pathway controls osmotic regulation of transcription via the stress response element of the Saccharomyces cerevisiae CTT1 gene. EMBO J. 13:4382-4389.

Torija, M.J., N. Rozès, M. Poblet, J.M. Guillamón, and A. Mas. 2003. Effects of fermentation temperature on the strain population of Saccharomyces cerevisiae. Int. J. Food. Microbiol. 80:47-53.

Van Dijck, P., P. Ma, M. Versele, M.F. Gorwa, S. Colombo, K. Lemaire, D. Bossi, A. Loïez, and J.M. Thevelein. 2000. A baker's yeast mutant ( $f i l l)$ with a specific, partially inactivating mutation in adenylate cyclase maintains a high stress resistance during active fermentation and growth. J. Mol. Microbiol. Biotech. 2:521-530.

Van Dijken, J.P., and W.A. Scheffers. 1986. Redox balances in the metabolism of sugar by yeasts. FEMS Microbiol. Lett. 32:199-224.

Zuzuarregui, A., P. Carrasco, A. Palacios, A. Julien, and M. del Olmo. 2005. Analysis of the expression of some stress induced genes in several commercial wine yeast strains at the beginning of vinification. J. Appl. Microbiol. 98:299-307. 